\title{
COMMENTARY
}

\section{Microbial ecosystem responses to rapid climate change in the Arctic}

\author{
Warwick F Vincent
}

The ISME Journal (2010) 4, 1089-1091; doi:10.1038/ ismej.2010.108; published online 15 July 2010

Rapid climate change in the Arctic has begun to affect the ecology of plants and animals throughout the region, with impacts on species ranges, population dynamics and food web interactions (Grebmeier et al., 2006; Post et al., 2009). By comparison, little attention has been given to the impacts on Arctic microbial communities, despite the major and often dominant contribution of microbes to total ecosystem biomass, biodiversity, nutrient cycling and energy flow. Some Arctic microbial ecosystems appear to be in rapid decline, whereas others are shifting towards new states, with implications for food webs and biogeochemical fluxes including greenhouse gas emissions. Given the accelerated rate of climate warming in the Arctic (Screen and Simmonds, 2010) and its potential effects on largescale microbial processes (Kirchman et al., 2009; Schuur et al., 2009), Arctic microbiota can be viewed both as sentinels and amplifiers of global change.

Ice forms the structural basis for many types of microbial ecosystem in the polar regions; small changes in temperature across the melting point can therefore have pronounced impacts on polar habitats and communities (Vincent, 1988). Global warming is causing a general attrition of the cryosphere, the ensemble of ice-containing environments on Earth. The continuous decline in annual sea ice is reducing the growing season for microbial communities that live in brine channels between the ice crystals and in the water column at the edge of the pack ice (marginal ice zone). In the Bering Sea region, these effects may account for decreased organic carbon fluxes to the seafloor and the observed reduction in benthic respiration rates (Grebmeier et al., 2006). Over the last decade, there has been a severe loss of multi-year sea ice, the $>3-\mathrm{m}$ thick ice formed by multiple years of accumulation. Only 20 years ago, this ice type covered about $80 \%$ of the Arctic Ocean (time series details at http://seaice.apl.washington.edu/), but little attention has been given to its microbial ecology. It can be expected that ongoing climate change will lead to the disappearance of this and other ice types, and their associated biota.
The thickest multi-year sea ice occurs as land-fast ice shelves along the northern coast of Ellesmere Island in high Arctic Canada. In addition to basal accretion by freezing of seawater, these also derive part of their mass from snowfall, and in the case of the Milne Ice Shelf, from glacier input. Abundant lakes and ponds melt out over the ice shelves each summer and these contain bottom sediments and benthic microbial mats. The mats are consortia of diverse Bacteria, Archaea and Eukarya (and associated viruses), but their main biomass constituents are oscillatorian cyanobacteria, including genotypes that are $>99 \%$ similar (in terms of $16 \mathrm{~S}$ rRNA gene sequences) to taxa previously thought to be endemic to Antarctica (Jungblut et al., 2010). The ice shelves are diminishing rapidly (Figure 1), and after millennia of existence their unique microbial ecosystems are now facing imminent extinction (Vincent et al., 2009).

The high Arctic ice shelves dam bays and fiords to create 'epishelf lakes', an unusual ecosystem type of freshwater overlying saltwater that is in tidal exchange with the sea. The fracturing and break-up of ice shelves is causing the draining and loss of their fresh and brackish water microbial communities. Epishelf lakes are well known from Antarctica, but after numerous losses over the last century, only one such ecosystem is thought to remain in the High Arctic, and it is vulnerable to ongoing warming (Veillette et al., 2008). A different type of ice-dammed lagoon occurs at the mouth of Arctic rivers. These persist for 6-9 months each year behind thick barriers of rubble ice (stamukhi) that form in the ice convergence zone, at the outer limit of land-fast sea ice. Studies on one such ecosystem at the mouth of the Mackenzie River showed that it is an active microbial ecosystem with distinct physical and microbiological properties (Galand et al., 2008). Stamukhi lakes are found throughout the circumpolar region and most likely have a key functional role in processing riverine inputs to the Arctic Ocean. Given their dependence on ice dynamics, these systems will respond strongly to ongoing climate change, with implications for the upstream flooding and residence time of water over river deltas, and for the transport of organic carbon and other terrigenous materials into the offshore ocean.

Melting sea ice combined with increasing freshwater delivery from river inflows is affecting the 

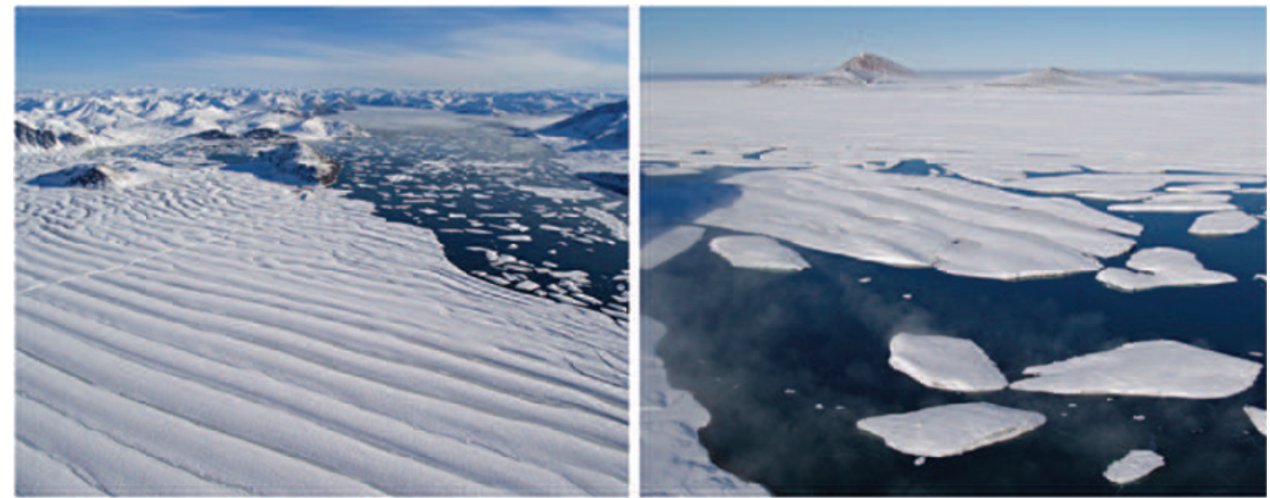

Figure 1 Fracturing and attrition of the Ward Hunt Ice Shelf ecosystem, high Arctic Canada, August 2008 (details in Vincent et al., 2009). Elongate meltwater lakes form in the troughs of the undulating ice each summer, and these contain microbial mat consortia of diverse bacteria and microbial eukaryotes (photographs: WF Vincent).

physical characteristics of the Arctic Ocean by causing reductions in the salinity of the surface mixed layer, which in turn results in greater hydrodynamic stability of the water column. These changes have been accompanied by increased bacterial concentrations, and also by a shift in phytoplankton size structure towards small microbial eukaryotes, notably, cold-adapted picoprasinophytes (Li et al., 2009). The latter are likely to be more competitive and less subject to sinking losses relative to larger phytoplankton in stratified, nutrient-poor conditions. However, these small cells are much less efficiently transferred within marine food webs and the resultant shifts may alter organic carbon export to fish communities and to benthic ecosystems. Such effects could be exacerbated by warmer temperatures that speed up respiration and microbial loop processes. A warmer Arctic Ocean may also be more susceptible to invasive species from the south, for example, the eventual replacement of picoprasinophytes by picocyanobacteria, and modification of dinoflagellate assemblages by the arrival of harmful algal bloom species. Both of these microbiological scenarios would most likely affect food quality, trophic processes and ecosystem services such as fisheries and shellfish harvesting (a traditional Inuit practice).

Arctic climate change is also influencing nonmarine microbial ecosystems. For example, northern lakes are experiencing longer periods of open water conditions, resulting in potentially greater primary production rates, but also disruption by windinduced mixing of vertically stratified microbial communities (Vincent et al., 2009). Erosion, warmer water temperatures and greater evaporation are causing a drying up of some Arctic freshwaters, but permafrost thawing in other regions is leading to the expansion of thermokarst lakes and ponds. These microbiological hot spots on the tundra are intense sites of microbial respiration and methanogenesis, and have the potential to produce globally significant effluxes of greenhouse gases from soil organic carbon pools that have accumulated over thousands of years (Laurion et al., 2010; and references therein). The microbiota of permafrost soil is itself responding to warming and deepening of the surface active layer. Gas flux studies have shown that permafrost thaw can result in microbial $\mathrm{CO}_{2}$ production rates that exceed plant carbon uptake, making permafrost a potentially large carbon source to the biosphere with ongoing climate change (Schuur et al., 2009).

As the Arctic continues to warm, psychrotrophs with their broad thermal tolerances are likely to flourish at the expense of psychrophiles. Microbial generalists invading from warmer latitudes will likely displace many of the resident specialists, and the retraction and loss of certain ice features such as perennial snow banks, multiyear sea ice, land-fast ice, glaciers and ice shelves will further reduce the opportunities for niche specialization. Arctic microbial ecosystems will retain their strong seasonality; however, there is likely to be greater biodiversity reflecting invasions from the south, faster biogeochemical kinetics in a warmer environment, increased extents of anaerobic and methanebased ecosystems, and in some regions, greater net production and emission of greenhouse gases. In the ocean, these changes will be compounded by the impacts of acidification and contaminants, and throughout the north polar region by increased human activities including shipping, mining, oil drilling and urbanization. In the new state of the Arctic, close attention will need to be paid to the structure and functioning of its diverse microbial ecosystems as global indicators and amplifiers of change.

\section{Acknowledgements}

I thank all members of our Arctic research group and the International Polar Year program MERGE (details at http:// www.cen.ulaval.ca/merge/); Connie Lovejoy and two anonymous referees for their constructive reviews; the Polar Continental Shelf Project and the Canadian Coast 
Guard for logistics support; and the Natural Sciences and Engineering Research Council, the Canada Research Chair program, the Fonds québécois de la recherche sur la nature et les technologies and the Networks of Centres of Excellence program ArcticNet for funding.

\section{WF Vincent is at Centre for Northern Studies (Centre} d'études nordiques), Département de biologie, Laval University, Quebec City, Quebec, Canada E-mail: warwick.vincent@bio.ulaval.ca

\section{References}

Galand PE, Lovejoy C, Pouliot J, Garneau M-E, Vincent WF. (2008). Microbial community diversity and heterotrophic production in a coastal Arctic ecosystem: a stamukhi lake and its source waters. Limnol Oceanogr 53: 813-823.

Grebmeier JM, Overland JE, Moore SE, Farley EV, Carmack EC, Cooper LW et al. (2006). A major ecosystem shift in the northern Bering Sea. Science 311: 1461-1464.

Jungblut A, Lovejoy C, Vincent WF. (2010). Global distribution of cyanobacterial ecotypes in the cold biosphere. ISME J 4: 191-202.

Kirchman DL, Morán XAG, Ducklow H. (2009). Microbial growth in the polar oceans-role of temperature and potential impact of climate change. Nature Rev Microbiol 7: 451-459.

Laurion I, Vincent WF, MacIntyre S, Retamal L, Dupont C, Francus $\mathrm{P}$ et al. (2010). Variability in greenhouse gas emissions from permafrost thaw ponds. Limnol Oceanogr 55: 115-133.

Li WKW, McLaughlin FA, Lovejoy C, Carmack EC. (2009). Smallest algae thrive as the Arctic Ocean freshens. Science 326: 539.

Post E, Forchhammer MC, bret-Harte MS, Callaghan TV, Christensen TR, Elberling B et al. (2009). Ecological dynamics across the arctic associated with recent climate change. Science 325: 1355-1358.

Schuur EAG, Vogel JG, Crummer KG, Lee H, Sickman JO, Osterkamp TE. (2009). The effect of permafrost thaw on old carbon release and net carbon exchange from tundra. Nature 459: 556-559.

Screen JA, Simmonds I. (2010). The central role of diminishing sea ice in recent Arctic temperature amplication. Nature 464: 1334-1337.

Veillette J, Mueller DR, Antoniades D, Vincent WF. (2008). Arctic epishelf lakes as sentinel ecosystems: past, present and future. J Geophys Res-Biogeosciences 113: G04014.

Vincent WF. (1988). Microbial Ecosystems of Antarctica. Cambridge University Press: Cambridge UK, pp 304.

Vincent WF, Whyte LG, Lovejoy C, Greer CW, Laurion I, Suttle CA et al. (2009). Arctic microbial ecosystems and impacts of extreme warming during the International Polar Year. Polar Science 3: 171-180. 